\title{
THE CORRELATION AMONG GENDER, LANGUAGE LEARNING STRATEGIES, AND ENGLISH ACHIEVEMENT OF ENGLISH DEPARTMENT STUDENTS OF TARBIYAH FACULTY AT UIN ALAUDDIN MAKASSAR
}

\author{
Maulina \\ lina821431@yahoo.com \\ Universitas Muhammadiyah Kendari
}

\begin{abstract}
This was a correlational research with two predictors and one criterion. 103 students (both successful and unsuccessful male and female students) were involved in this research. The data obtained through SILL by Oxford (1990) and students' English achievement based on gender were analyzed by using descriptive statistics and inferential statistics through SPSS program version 20.0. The findings, first of all showed that there was a significant correlation between gender and English achievement where $r=0.924$ and $p=0.000<\alpha=$ 0.05 . Second, there was not any significant correlation between LLSs and English achievement where $r=0.202$ and $p=0.083>\alpha=0.05$. Third, there was not any significant correlation between successful gender and their LLSs where $r=0.222$ and $p=0.056>\alpha=0.05$ but there was a significant correlation between unsuccessful gender and their LLSs where $r=-0.376$ and $p=0.049<\alpha=0.05$. Fourth, There was a significant correlation between gender and LLSs used simultaneously with English achievement where $r=0.264$ and $p=$ $0.04<\alpha=0.05$.
\end{abstract}

Keywords: gender, language learning strategies, English achievement

\begin{abstract}
Abstrak
Penelitian ini adalah studi korelasi dengan dua predictor dan satu kriteria. 103 mahasiswa (mahasiswa laki-laki dan perempuan baik yang berhasil maupun tidak berhasil) dilibatkan dalam penelitian ini. Data diperoleh melalui SILL Oxford (1990) dan pencapaian Bahasa Inggris mahasiswa berdasarkan gender dianalisis menggunakan statistik deskriptif fan inferensial statistik menggunakan program SPSS versi 20.0. Pertama, hasil penelitian menunjukkan bahwa ada korelasi signifikan antara gender dan pencapaian Bahasa Inggris di mana $r=0.924$ dan $p=0.000<\alpha=0.05$. Kedua, tidak ada korelasi signifikan antara LLSs dan pencapaian Bahasa Inggris di mana $r=$ 0.202 dan $p=0.083>\alpha=0.05$. Ketiga, tidak ada korelasi signifikan
\end{abstract}


antara gender yang berhasil dan LLSs dimana $r=0.222$ dan $p=0.056$ $>\alpha=0.05$ tapi ada korelasi signifikan antara gender yang tidak berhasil dan LLSs mereka di mana $r=-0.376$ dan $p=0.049<\alpha=$ 0.05. Keempat, ada korelasi signifikan antara gender dan LLSs yang digunakan secara serempak dengan pencapaian Bahasa Inggris di mana $r=0.264$ dan $p=0.04<\alpha=0.05$.

Keywords: gender, strategi pembelajaran bahasa strategies, pencapaian Bahasa Inggris

\section{Introduction}

In learning English as foreign language, many factors can influence the learners to be successful to learn it. In this case, there are some elements to make the process of learning possible in various situations and places such as teachers, facilities, students, material, goals, time, and place. All of them are interwined each other.

The success in learning language is also much influenced by strategies run by the learners. There seems to be no question that foreign language learners should be equipped with appropriate learning strategies in order to learn target language more effectively and efficiently because language learning is an intentional and strategic effort (Chamot \& O’Mellay, 1996; Oxford, 1990).

Use of appropriate learning strategies enables students to take responsibility for their own learning by enhancing learner autonomy, independence, and self-direction. These factors are important because learners need to keep on learning even when they are no longer in a formal classroom setting (Oxford, 1990:42).

Various researchers have studied factors related to choice of language learning strategies, as shown in a review (Oxford, 1990:40). These factors include: 1) language being learned; 2) level of language learning, proficiency, or course; 3) degree of metacognitive awareness; 4) gender; 5) affective variables such as attitudes, motivation, and laanguage learning goals; 6) specific personality traits; 7) overall personality type; 8) learning style; 9) carreer orientation or field of specialization; 10) national origin; 11) aptitude; 12) language teaching methods; 13) task requirements; and 14) type of strategy training. Many of these factors, such as language learning level, national origin, field of specialization, 
and language teaching methods, have been definitively shown to be strongly related to language learners' choice of strategies. But others, such as motivation and gender, have until now not received sufficient research attention to allow firm conclusions to be reached.

It was therefore clear that to be able to fully understand the nature of SLA (Second Language Acquisition), it needed to have a deeper understanding of the bilateral interrelation between gender and language learning strategies. In addition, although once simplistically regarded in terms of male or female, gender is now understood to be much more complicated phenomenon which is at least partially socially constructed. The correlation between gender and language learning strategies, however, is still not well understood. It still needs considerably more research in order to clarify how gender is interpreted and how it takes its place in a complex web of characteristics that define as human beings and as learners.

\section{Research Question}

This study sought to answer the following questions:

1. Is there any significant correlation between gender (successful and unsuccessful both male and female students) and their English achievement of English Department of Tarbiyah Faculty, UIN Alauddin Makassar?

2. Is there any significant correlation between language learning strategies used by gender (successful and unsuccessful both male and female students) and their English achievement?

3. Is there any significant correlation between gender (successful and unsuccessful both male and female students) and their language learning strategies in learning English?

4. Is there any significant correlation between gender (successful and unsuccessful both male and female students) and their language learning strategies they used simultaneously with their English achievement?

\section{Previous Related Findings}

Learning strategies have received much attention since the late 1980s (Oxford, 2008) and the investigation of language learning strategies has advanced 
the understanding of the processes learners use to develop their skills in a second or foreign language.

Aydin (2003) did a research entitle 'Language Learning Strategies Used by Turkish High School Students Learning English.' He found that there was a positive correlation between strategy use and achievement, yet he found that there was not any significant difference between males and females in terms of language learning strategies use. His findings also showed that the least preferred strategies were the affective strategies and the attribute this to the fact that students learned the target language in Turkish setting, where they had no opportunity to practice the target languae and therefore did not need to use such strategies. Aslan (2009) investigated the language learning strategies used by learners of English as a foreign language, aiming to find the amount of strategies and the domain differences of the strategies used, to reveal the link between strategy use and success levels, and to find out the difference in strategy use between gender and its influence on the students' achievement in English. He found that females were significantly more successful than males in terms of achievement tests, and they used more language learning strategies in learning English. Further, he also found that there is a significant connection between gender, language learning strategies and achievement in English.

Haryanto (1999) conducted a research under the tittle "Motivation and Learning Strategies of a Good Indonesian EFL Learner.” He investigated deeply a good Indonesian EFL learner named Indra. What learning strategies are performed by him does his motivation operate to achieve success of English as Foreign Language (EFL) in Indonesian context. By applying grounded theory approach, he concluded that there are two main factors determine the success of Indra in learning English, namely motivation and learning strategies. Besides that, there are also other factors peripherally give contribution to his success. Those are attitude, intelligence, parents' role, material design, school environment, and school policy.

Simsek (2010) conducted a research about learning strategies of successful and unsuccessful university students in Turkey. The researcher found that successful students used more, varied, and better learning strategies than 
unsuccessful students. Female students were more effective in selecting and using appropriate strategies than male students. There were a variety of differences among fields of the study; students of fine arts used the strategy least, while students of sports used them the most. The most preferred group of strategies was metacognitive strategies, whereas the least preferred group was organization strategies. The same pattern was found for the level of success, gender, and the field of the study. The results overall implied that certain strategies contribute to student performance more than other strategies, and majority of university students were aware of this situation.

\section{Research Method}

\section{Research Design}

This was a correlational research with two predictors and one criterion. The correlational research paradigm was as follows:

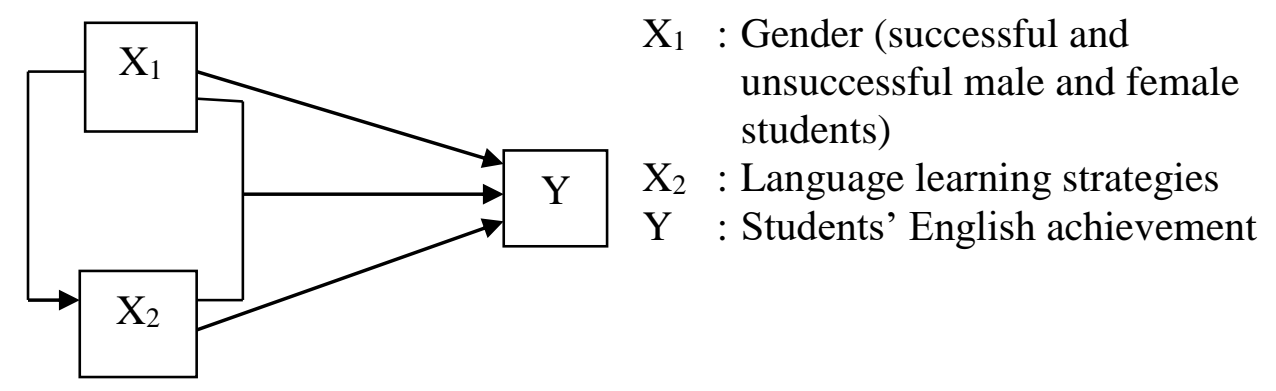

First of all, this research found out the significant correlation between gender (successful and unsuccessful both male and female students) and their English achievement. Secondly, it found out the significant correlation between language learning strategies used by gender (successful and unsuccessful both male and female students) and their English achievement. Next, it found out the significant correlation between successful and unsuccessful both male and female students, and their language learning strategies in learning English. Last, it found out the significant correlation between gender (successful and unsuccessful both male and female students) and their language learning strategies used simultaneously with their English achievement. 


\section{Population and Sample}

This research conducted at students of English Department of Tarbiyah Faculty, UIN Alauddin Makassar. The total of population was 379 students. The proportionate stratified random sampling. Based on the document analysis, the successful males consisted of 27 students and unsuccessful ones consisted of 10 students. While, the successful females consisted of 48 students and unsuccessful ones consisted of 18 students. The sample was 103 students.

\section{Research Instrument}

There were two kinds of instrument in this research. They were SILL (Oxford, 1990) and documentation of students' English achievement. SILL has a validity (0.367) and high reliability where the Cronbach's Alpha was 0.953. In this research, successful students were identified as those who had scores range from 76 - 100. Meanwhile, unsuccessful students were identified as those who had scores less than 66 .

\section{Data Collection Procedure}

Before conducting the research, the researcher first informed the administration of the institution about the study and received the required permission. After having that, the researcher asked permission also to the lecturers who had schedule teaching at the time. The researcher got into the class introducing herself and telling the purpose of the research that it was not to test them but it aimed to see their learning strategies in learning English. She also told them that there were not right and wrong answer of the statements on SILL. It was what they do in learning English. It was about 30 minutes students filled out the SILL. The distibution of SILL was done to all students of English Department of Tarbiyah Faculty at UIN Alauddin Makassar because it made the researcher easily to determine who was involved in this research. The second data namely students' English achievement got from administration staff of English Department. The SILL filled out by those students was matched with their English lesson average scores, or whose SILL had whose English lesson average score.

\section{Technique of Data Analysis}

The data that is collected through SILL and students' English achievement based on gender were analyzed using SPSS windows 20. The analyses were done 
in order of the research questions. Before testing the hypotheses of this research, the researcher did the normality distribution test and test of homogeneity of variances which were aimed to see whether the statistics test used in this research involved parametric or non-parametric statitistics. The purpose of normality test was to see both independent and dependent variable have or have not a normal distribution in order to avoid the data bias (Wijaya, 2102:132). In addition, test homogeneity of variance was used to see two or more groups of data sample were from population which have the same varians. The data has normal distribution and homogeneity of variace where Sig. (2-tailed) is higher than $\alpha=.05$, then the data distribution is normal and homogeneity of variance is proved that the sample represent the population (Wahyono, 2002). In this reserach, parametric statistics were applied because the normality distribution test of Kolmogorov-Smirnov sig. (2-tailed) $=0.200$ was higher than $\alpha=0.05$ and homogeneity of variance sig. (2tailed) $=0.720$ was higher than $\alpha=0.05$.

After testing the normality distribution and homogeneity of variance of the data, the researcher then tested the fifth research hypotheses. First, the simple correlation or Product Moment correlation (bivariate correlation) was applied at the first, the second, and the third research questions. Partial correlation was applied at the fourth research question.

In order to identify the degree of correlation, the interpretation of correlation coefficient was as follows:

Table 1. The Interpretation of Correlation Coefficient

\begin{tabular}{cc}
\hline Coefficient Interval & Degree of Correlation \\
\hline Less than $+/-.35$ & Low \\
Between $+/-.36$ and $+/-.65$ & Moderate \\
Above $+/-.66$ & High \\
\hline
\end{tabular}

(Gay et al., 2006:194)

\section{Findings and Discussion}

\section{Gender and English Achievement}

To test the alternative hypothesis $\left(\mathrm{H}_{1}\right)$ of research question number one that there is a significant correlation between gender (successful and unsuccessful both male and female students) and their English achievement of English Department of Tarbiyah Faculty at UIN Alauddin Makassar, the Product Moment 
correlation was run. First of all, successful gender was correlated by English achievement. Then, unsuccessful gender was also correlated by English achievement. The results showed that alternative hypothesis $\left(\mathrm{H}_{1}\right)$ was accepted where Pearson correlation for successful gender and English achievement was $r=$ 0.924 and unsuccessful gender and English achievement was $r=0.909$ and Sig. (2-tailed) was 0.000 less than $\alpha=0.05$. Gay et al. (2006: 358) state that if the $p$ value "Sig. (2-tailed) is less than or equal to $\alpha=0.05$, then there is a significant correlation between gender and English achievement. It indicated that the successful the students, the higher the score they gain. In addition, the unsuccessful the students, the lower the score in learning English they achieve.

\section{LLSs and English Achievement}

To test the alternative hypothesis $\left(\mathrm{H}_{1}\right)$ of research question number two that there is a significant correlation between language learning strategies used by gender (successful and unsuccessful both male and female students) and their English achievement, the Product Moment correlation was run. First of all, LLSs used by successful gender was correlated by English achievement. Then, LLSs used by unsuccessful gender was also correlated by English achievement. The results showed that alternative hypothesis $\left(\mathrm{H}_{1}\right)$ was rejected where Pearson correlation for LLSs used by successful gender and English achievement was $r=$ 0.202 and Sig. (2-tailed) was 0.083 , then LLSs used by unsuccessful gender and English achievement was $r=-0.352$ and Sig. (2-tailed) was 0.067 higher than $\alpha=$ 0.05. These were happened because total responses on SILL showed that both successful and unsuccessful students gave almost similar number of responses.

\section{Gender and LLSS}

To test the alternative hypothesis $\left(\mathrm{H}_{1}\right)$ of research question number three that there is a significant correlation between gender (both successful and unsuccessful both male and female students) and their LLSs in learning English, the Product Moment correlation was run. First of all, successful gender was correlated by LLSs used by them. Then, unsuccessful gender was correlated also by LLSs used by them. The results showed that alternative hypothesis $\left(\mathrm{H}_{1}\right)$ was

rejected for correlation between successful gender was correlated by LLSs used by them where Pearson correlation was $r=0.222$ and Sig. (2-tailed) was 0.056 
higher than $\alpha=0.05$. On the other hand, alternative hypothesis $\left(\mathrm{H}_{1}\right)$ was accepted for correlation between unsuccessful gender was correlated by LLSs used by them where Pearson correlation was $r=-0.376$ and Sig. (2-tailed) was 0.049 lower than $\alpha=0.05$.

The successful students (male and female) achieved the high scores in learning English since they applied more language learning strategies, for instance memory strategies (I review English lessons often). But, in this research both unsuccessful male and female students also used those strategies (as listed on SILL) often eventhough their English achievement were 66 below.

\section{Gender, LLSs, and English Achievement}

To test the alternative hypothesis $\left(\mathrm{H}_{1}\right)$ of research question number four that there is a significant correlation between gender (successful and unsuccessful both male and female students) and their language learning strategies used simultaneously with their English achievement, the partial correlation was run. The result showed that the partial correlation between LLSs used by gender (successful and unsuccessful both male and female students) and their English achievement without control variable from gender (successful and unsuccessful both male and female students) was 0.193. However, when the control variable from gender (successful and unsuccessful both male and female students) exists between them, the partial correlation was 0.264 . It implies that the correlation of control variable from gender (successful and unsuccessful both male and female students) was low. The significance (2-tailed) is 0.04 lower than $\alpha=0.05$, then there is a significant correlation among gender, LLSs, and English achievement. The alternatif hypothesis $\left(\mathrm{H}_{1}\right)$ was accepeted where there is a significant correlation between gender and LLSs used simultaneously with English achievement.

This research showed that both successful and unsuccessful male and female students seemed to be aware of their language needs. They tend to utilize strategies that help them master the target language through practicing, reasoning, analyzing, as well as strategies that allow them to control their own learning through planning and evaluating learning. 


\section{Conclusion}

1. There was a significant correlation between gender (both successful and unsuccessful male and female students) and English achievement where coefficient correlation of successful gender and English achievement was $r=$ 0.924 and $p=0.000<\alpha=0.05$. Similarly, coefficient correlation of unsuccessful gender and English achievement $r=0.909$ and $p=0.000<\alpha=$ 0.05 .

2. There was not any significant correlation between LLSs used by gender (both successful and unsuccessful male and female students) and English achievement where correlation coefficient of LLSs used by successful gender and their English achievement was $r=0.202$ and $p=0.083$ was higher than $\alpha$ $=0.05$. Similarly, correlation coefficient of LLSs used by unsuccessful gender and their English achievement was $r=-0.352$ and $p=0.067$ was higher than $\alpha=0.05$.

3. There was not any significant correlation between successful gender and their LLSs where $r=0.222$ and $p=0.056>\alpha=0.05$. On the other hand, there was a significant correlation between unsuccessful gender and their LLSs where $r$ $=-0.376$ and $p=0.049<\alpha=0.05$.

4. There was a significant correlation between gender and LLSs used simultaneously with English achievement where $r=0.264$ and $p=0.04<\alpha$ $=0.05$.

\section{Suggestion and Recommendation}

1. Teacher should raise students' awareness about LLSs and their usefulness. Greater student awareness about LLSs can help them to become more self confident and successful language learners.

2. Students should also be made aware that a wider repertoire of LLSs and higher frequency of their use are both critical in learning language effectively.

3. This research came up with answers relating gender (successful and unsuccessful male and female students), language learning strategies and English achievement. However, further research is needed to better understand their interconnection and test their accuracy. 
4. There were some factors affecting the choice of language learning strategies like motivation, attitude, learning style, economic situation, social background that create a difference between genders should be involved in further research.

\section{References}

Agnihotri, R.K., 1979. Process of Assimilation: Sociolinguistic Study of Sikh Children in Leeds. Unpublished DPhil thesis. In Khanna, A. L., Verma, M.K., Agnihotri, R.K. and Sinha, S. K. Adult ESOL Learners in Britain: A Cross-Cultural Study (pp.58-81). University of York: York.

Aydin. T. 2003. Language Learning Strategies Used by Turkish High School Students Learning English. Foreign Language Annals, 103 (1), 13-24

Arifin. Bahri. 2000. Language Learning Strategy in Second Language Acquisition by Adult Learners of English in the Indonesian Context. Unpublished Dissertation. PPs - UNHAS Makassar.

Arikunto, S. 2006. Prosedur Penelitian. Suatu Pendekatan Praktik. Jakarta: Rineka Cipta.

Aslan. O. 2009. The Role of Gender and Language Learning Strategies in Learning English. Foreign Language Annals, 22(8), 13-24. Retrieved from http://etd.lib.metu.edu.tr/upload/12611098/index.pdf.

Bergvall, V. 1999. Towards a Comprehensive Theory of Language and Gender. Language in Society, 28, 273-293.

Block, D. 2002. Language \& Gender and SLA. [Electronic version] Quaderns de Filologia. Estudis Linguistics. Vol VII, 49-73.

Butler, J. 1990. Gender Trouble: Feminism and the Subversion of the Identity. New York: Routledge.

Cambridge Advance Learner's Dictionary $3^{\text {rd }}$ Edition. 2008. Cambridge University Press.

Cameron, D. 1990. Feminism and Linguistic Theory (2nd ed.). London: Macmillan. 
Cameron, D. 1995. Rethinking language and gender studies: Some issues for the 1990s. In Mills, S. (ed.). Language and Gender: Interdisciplinary Perspectives (31-44). London: Routledge.

Cameron, D. 2004. Language, Gender, and Sexuality: Current Issues and New Directions. Applied Linguistics 26/4, 482-502. Oxford University Press.

Chamot, A. \& Kupper, L. 1989. Learning Strategies in Foreign Language Instruction. Foreign Language Annals, 22(1), 13-24.

Collins Cobuild English Dictionary. 1995. London: Harper Collins Publishers.

Cooper, R. L. 1989. Language Planning and Social Change. New York: Cambridge University Press.

Davis, K.A. \& Skilton-Sylvester, E. 2004. Looking Back, Taking Stock, Moving Forward: Investigating Gender in TESOL. TESOL Quarterly 38/3, 381404.

Ehrman, M. E., \& Oxford, R. L. 1989. Effects of Sex Differences, Career Choice, and Psychological Type on Adult Language Learning Strategies. The Modern Language Journal, 73, 1-13.

Ellig, J. R. \& Morin, W.W. 2001. What Every Successful Woman Knows. New York: McGraw-Hill

Ellis, R. 1994. The Study of Second Language Acquisition. Oxford: Oxford University Press.

Furwana, D. 2012. Learning Strategies of Sixth Semester Students of English Department of Tarbiyah Faculty at UIN Alauddin Makassar. Unpublished Thesis. Makassar: Universitas Negeri Makassar.

Gay, et al. 2006. Educational Research. New Jersey: Pearson Prentice Hall.

Giddens, A. 1991. Modernity and Safe Identity. London: Polity.

Green, J. \& Oxford, R. 1995. A Clooser Look at Learning Strategies, L2 Proficiency, and Gender. TESOL Quarterly, 29 (2), 261-297.

Haryanto. 1999. Motivation and Learning Strategies of a Good Indonesian EFL Learner. Unpublished Dissertation. Jakarta: PPs IKIP Jakarta.

Haryanto. 2008. Metode Penelitian Kualitatif: Teori Dasar. Makassar: Badan Penerbit Universitas Negeri Makassar. 
Haryanto. 2011. Case Study Method in TEFL Studies. A Paper Presented to the Doing Research in Apllied Linguistics Conference. Bangkok, 21-22 April 2011.

Khalil, A. 2005. Assessment of Language Learning Strategies Used by Palestinian EFL Learners. Foreign Language Annals, 38 (1), 108-119.

Lakoff, R. 1973. Language and Woman's Place. Language in Society, 2, 45-80.

Li, R. \& Bu, Y. 2006. On How Children Acquire Their Mother Tongue: Explanation of Chomsky' Mental Linguistic Theory. Sino-US English Teaching 3/ 3, 55-57.

Lin, A. \& Luk, J. 2004. Local Creativity in the Face of Global Domination: Insights of Bakhtin for Teaching English for Dialogic Communication. In Hall, J. K., Vitanova, G. \& Marchenkova, L. (Eds.), Contributions of Mikhail Bakhtin to Understanding Second and Foreign Language Learning. Mahwah, NJ: Lawrence Erlbaum.

Maccoby, E.E \& Jacklin C.E. 1974. The Psychology of Sex Differences. Stanford: Stanford University Press.

Mahmud, M. 2009. Bahasa dan Gender dalam Masyarakat Bugis. Makassar: Indonesia: Pustaka Refleksi.

Nichols, P. C. 1999. The Role of Social Networks and the Strength of Weak Ties in Changing Language Policy: Gender Neutralization in American English. In Huebner, T. \& Davis, K. A. (Eds.), Sociopolitical Perspectives on Language Policy and Planning in the USA (pp. 67-98). Philadelphia: John Benjamins.

Nugroho, Riant. 2011. Gender dan Strategi Pengarus-Utamaannya di Indonesia. Yogyakarta: Pustaka Pelajar.

Nurlailah. 2012. Effective Learning Strategies Applied by the English Learners in AL MARKAZ for Kuhdi Enlightening Students (MAKES). Unpublished Thesis. Makassar: Universitas Negeri Makassar.

O'Malley, J. M., \& Chamot, A.U. 1990. Learning Strategies in Second Language Acquisition. Cambridge: Cambridge University Press.

Oxford, R. L. 1989. Use of Language Learning Strategies: A Synthesis of Studies with Implications for Strategy Training. System, 17, 235-247. 
Oxford, R. \& Nyikos, M. 1989. Variables Affecting Choice of Language Learning Strategies: a Synthesis of Studies with Implications for Strategy Training. System, 17, 235-247.

Oxford, R. \& Ehrman, M. 1995. Adults' Language Learning Strategies in an Intensive Foreign Language Program in the United States. System, 23 (3), 359-386.

Oxford, R. L. 1990. Language Learning Strategies: What Every Teacher Should Know. New York: Newbury House.

Rigney, J. W. 1978. Learning Strategies: A Theoretical Perspective. In H. F. O’Neil, Jr. (Ed.), Learning Strategies (pp. 165-205). NY: Academic.

Rubin, J., and Thompson, I. 1982. How to be a more successful language learner. Boston: Heinle \& Heinle.

Schemeck, R. R. (Ed.). 1988. Learning Strategies and Learning Styles. New York, NY: Plenum Press.

Shmais, W. 2003. Language Learning Strategy Use in Palestine. TESL-EJ, 7 (2). Retrieved from http://tesl-ej.org/ej26/a3.html.

Simsek, Ali. 2010. Learning Strategies of Succesful and Unsuccessful University Students. Contemporary Educational Technology. Turkey: Anadolu University. 36-45.

Stern, H. H. 1975. What Can We Learn from the Good Language Learner? Canadian Modern Language Review. 34, 304-318.

Sugiyono. 2013. Metode Penelitian Pendidikan: Pendekatan Kuantitatif, Kualitatif, dan R\&D. Bandung: Penerbit Alfabeta.

Tannen, D. 1993. Introduction. In Tannen, D. (Ed.), Gender and Conversational Interaction (pp. 3-13). New York: Oxford University Press.

Tannen, D. 1996. Researching Gender-Related Patterns in Classroom Discourse. TESOL Quarterly, 30, 341-344.

Wahyono, T. 2002. Analisis Statistik Mudah dengan SPSS 20. Jakarta: Penerbit PT Elex Media Komputindo.

Weda, S. 2005. English Learning Strategies Employed by Senior Secondary School Students. Unpublished Dissertation. PPs-UNHAS Makassar. 
Weinstein, C. E., \& Mayer, R. E. 1986. The Teaching of Learning Strategies. In M. C. Wittrock (Ed.), Hand-Book of Research on Teaching, $3^{\text {rd }}$ edition (pp. 315-327). New York: Macmillan.

Wello, Muhammad Basri et al. 1993. Strategy Belajar Bahasa Inggris FPBS IKIP Ujung Pandang (Students' English Learning Strategy of English Education at FPBS IKIP Ujung Pandang). Makassar: FPBS IKIP Ujung Pandang.

Wenden, A. 1990. 'Helping Language Learners Think about Learning' in Currents of Change in English Language Teaching ed. By Rossner and Bolitho OUP (p.174).

Wenden, A. \& Rubin, J. 1987. Learner Strategies: Theoritical Assumptions, Research History and Typology. New Jersey: Prentice/Hall International.

Wharton, G. 2000. Language Learning Strategy Use of Bilingual Out the Best in a Learner. TESL Canada Journal. 8(2), 45-56.

Wijaya. T. 2012. Praktis dan Simpel Cepat Menguasai SPSS 20 untuk Olah Data: Data Penelitian dan Skripsi. Yogyakarta: Cahaya Atma Pustaka. 